\title{
Antigenic properties of serration bacteriophages
}

\author{
L.G. Molochaeva, R.Kh. Gayrabekov, and T.I. Gayrabekova \\ FSBEI HE "Chechen State University", 31, st. L. Yashina, Grozny, 364049, Russia
}

\begin{abstract}
The genus Serratia is one of the poorly studied among enterobacteria, which explains the interest in these microorganisms and bacteriophages active towards these microorganisms. The aim of this work was to study the antigenic properties of bacteriophages isolated by us from lysogenic cultures of serrations and from environmental objects. The work investigated 16 phages active against bacteria Serratia marcescens, isolated from various sources.
\end{abstract}

\section{Introduction}

In recent decades, special attention of health authorities has been drawn to the problem of nosocomial infections, which sharply reduce the effectiveness of therapeutic measures, increase the length of stay of patients in hospitals, and increase mortality. The problem of nosocomial infections is classified by WHO as one of the urgent and priority problems of modern medicine. Currently, the urgency of the problem of nosocomial infections has especially increased in the light of the new pandemic caused by the SARS-CoV-2 virus.

Coronavirus Disease 2019 (COVID-19) - a disease caused by a new coronavirus, now called Severe acute respiratory syndrome-related coronavirus 2 (SARS-CoV-2); previously called 2019-nCoV), first identified during an outbreak of respiratory disease in Wuhan City, Hubei Province, China [12]. This was originally reported to the World Health Organization (WHO) on December 31, 2019, already on January 30, 2020, WHO declared the outbreak of COVID-19 as a global health emergency [13, 20], on March 11, 2020, WHO declared COVID-19 a global pandemic, first calling it such since the announcement of the H1N1 influenza pandemic in 2009 [22].

The risk of attaching a bacterial infection with COVID-19 disease increases if the patient is admitted to the hospital and at the same time has chronic pathology of the upper and lower respiratory tract or heart failure.

In conditions of reduced respiratory and motor activity, when mucus moves through the bronchi less, against the background of intoxication of the body and a decrease in immunity, bacteria from the nasopharynx descend into the lower parts of the respiratory tract and can begin to multiply there.

Therefore, first bacterial bronchitis can be caused, then bronchopneumonia with the transition to pneumonia. Development of bacterial pneumonia can also be facilitated by a long stay of the patient on the ALV. Despite the observance of all the strictest disinfection measures, ALV are risk factors for occurrence of ventilator-associated pneumonia. 
Some species belonging to the genus Serratia are representatives of the group of opportunistic microorganisms that are most often isolated from patients during outbreaks of nosocomial infections; they are at the forefront of this process. Thus, for the first time, the role of Serratia marcescens in the pathological process was noted in 1913 [23], however, in recent decades, not only Serratia marcescens were isolated, but along with them, other representatives of this genus, such as Serratia liquefaciens, S. plymuthica, S. ficaria, Serratia odorifer, Serratia plymuthica were isolated [15, 16, 18, 22, 24, 25].

The genus Serratia is one of the poorly studied among enterobacteria, which explains the interest in these microorganisms and bacteriophages active towards these microorganisms.

Information on bacteriophages active against bacteria of the genus Serratia is very limited. In the available references, we came across only four papers in which such bacteriophages were mentioned. So in the paper of Seifert-Gertchman N. and Lippert W. [21], the moderate bacteriophage Kappa is described and some of its sizes are given. Matthews M. and Bradley D.E. [17] mention bacteriophage SM2. Bradley D.E. gave some sizes and morphology of bacteriophages SMB1, SM4, SMPA, SM2, SMP, SMP5, SMB3 [11].

Pitt T.L., Erdman I.J., Bucher C. described a system consisting of 10 bacteriophages active against bacteria of the genus Serratia, with the help of which they carried out typing of bacteria belonging to this genus in England [19].

Bacteriophages active against bacteria of the genus Serratia were studied by R.Kh. Gairabekov and coauthors. They examined the morphological, physiological, antigenic properties, the specificity of the bacteriophages isolated by them in relation to representatives of different species of the genus Serratia, as well as to representatives of different genera of the family Enterobacteriaceae [3-6], as a result of which they offered a typing scheme for bacteria belonging to the genus Serratia.

\section{Materials and Methods}

In this paper, 61 bacterial strains belonging to the genus Serratia were used, of which 57 cultures belonged to the species Serratia marcescens and 4 cultures — to the species Serratia liquefaciens [7]. These cultures were characterized by heterogeneity in a number of biological characteristics, including the presence of pathogenicity factors (sensitivity to antibiotics, lysozyme activity, antilysozyme activity, hemolytic activity, adhesive properties. The presence of plasmids, and etc.) $[8,9,12]$.

The paper investigated 16 bacteriophages active against bacteria Serratia marcescens, isolated from various sources. Where, 15 bacteriophages were isolated from lysogenic cultures by cross-testing cultures on plates with $1.5 \%$ nutrient agar. Wherein, all studied Serratia cultures were used both as indicator and as lysogenic.

One bacteriophage was isolated from the water of an open reservoir by seeding $1 \mathrm{ml}$ of water with a two-layer method with $0.3-0.5 \mathrm{ml}$ of a broth culture of the indicator strain and subsequent passaging of the bacteriophage from the resulting negative colonies.

When working with phages, we used the generally accepted methods of their isolation and study, given in the manuals of M. Adams [10] and I.M. Gabrilovich [1,2].

The study of the antigenic properties of bacteriophages was carried out in the reaction of neutralization with rabbit sera according to the generally accepted method. To obtain antiphage sera, rabbits were immunized with bacteriophage suspensions containing1мл $10^{8}-10^{9}$ infectious particles.

Two courses of immunization were carried out, which consisted of three injections with intervals between injections of 2-3 days. The interval between courses of immunization was 7 days. 
Neutralization of bacteriophages was carried out at the temperature of $37^{\circ} \mathrm{C}$ in an ultrathermostat. The percentage of bacteriophage neutralization was noted and the neutralization rate constant was calculated using the formula:

$$
\mathrm{K}=\frac{2,3 \cdot \lg P_{0} / P \cdot D}{t}
$$

where $P_{0}$ and $\mathrm{P}$ - titers of bacteriophages, before and after incubation with antiphage serum, $D$ - whey dilution, $t$ - incubation time.

For the titer of antiphage serum, we took the highest dilution of it, which provided neutralization of at least $90 \%$ of the homologous bacteriophage at the minimum exposure.

\section{Study Results}

To obtain antiphage sera, three rabbits were immunized with bacteriophages, which were selected for the difference in the morphology of negative colonies and the spectrum of action. The obtained sera had a relatively low activity, which indicates the weak antigenic properties of our bacteriophages active against bacteria of the genus Serratia, the rate constants for neutralization by the obtained sera of homologous bacteriophages were within 1.3-1.48 $\mathrm{min}^{-}$ ${ }^{1}$. The titers of the obtained sera were 1:10, the minimum exposure for all sera was 30 minutes (Table 1).

Table 1. Characteristics of antiphage sera.

\begin{tabular}{|c|c|c|c|c|c|c|}
\hline Serum & $\begin{array}{c}\text { Number of } \\
\text { immunization } \\
\text { courses }\end{array}$ & $\begin{array}{c}\text { Phage } \\
\text { injected }\end{array}$ & $\begin{array}{c}\text { Serum } \\
\text { titer }\end{array}$ & $\begin{array}{c}\text { Exposure } \\
\text { in } \\
\text { minutes }\end{array}$ & $\begin{array}{c}\text { \% } \\
\text { neutralization }\end{array}$ & $\begin{array}{c}\text { Neutralization } \\
\text { rate constant }\end{array}$ \\
\hline $32 / 23$ & 2 & $17 \times 10^{9}$ & $1: 10$ & 30 & 98.1 & 1.3 \\
\hline $\mathrm{P} / 5$ & 2 & $25.8 \times 10^{9}$ & $1: 10$ & 30 & 99.5 & 1.33 \\
\hline $29 / 10$ & 2 & $74.1 \times 10^{9}$ & $1: 10$ & 30 & 99.4 & 1.48 \\
\hline
\end{tabular}

Also in this paper, to test the specificity of the antigenic properties of bacteriophages serrations, we used serum obtained to the bacteriophage Enterobacter $\mathrm{C}_{14}$.

The results obtained in the experiments on the neutralization of phages indicate the presence of common antigens in the studied phages active against bacteria of the genus Serratia. The data obtained make it possible to distinguish 4 serological types among the studied bacteriophages.

The first serotype includes 11 bacteriophages $(32 / 23,31 / 23,30 / 23,28 / 23,23 / 23,17 / 23$, $27 / 21,25 / 25,24 / 24,20 / 20,12 / 12$ ). Considering the differences in the antigenic properties of these bacteriophages, we considered it possible to distinguish subtypes within this type. Bacteriophages 32/23, 31/23, 30/23, 23/23, 17/23, 25/25, 24/24 and 12/12 are assigned to subtype Ia, since these bacteriophages were inactivated only by serum obtained to bacteriophage $32 / 23$. Bacteriophage $28 / 23$ was assigned to subtype $\mathrm{Ib}$, on the basis that this bacteriophage was completely inactivated by sera obtained to bacteriophages $29 / 10$ and $\mathrm{P} / 5$. Bacteriophage 27/21 was classified as subtype Ic, because it was completely inactivated by the serum obtained against bacteriophage $32 / 23$, and partially inactivated by serum to bacteriophage 29/10. Bacteriophage 20/20 was isolated into a separate subtype Id, since it was completely inactivated by serum to bacteriophage $32 / 23$ and partially by serum to bacteriophage $\mathrm{P} / 5$. 
Table 2. Antigenic connections of serration bacteriophages.

\begin{tabular}{|c|c|c|c|c|c|}
\hline \multirow{2}{*}{ Serotype } & \multirow{2}{*}{ Phage } & \multicolumn{4}{|c|}{ Serums } \\
\hline & & $32 / 23$ & $29 / 10$ & $P / 5$ & $C 14$ \\
\hline Ia & $32 / 23$ & & & & \\
\hline Ia & $31 / 23$ & & & & \\
\hline Ia & $30 / 23$ & & & & \\
\hline Ia & $23 / 23$ & & & & \\
\hline Ia & $17 / 23$ & & & & \\
\hline Ia & $25 / 25$ & & & & \\
\hline Ia & $24 / 24$ & & & & \\
\hline Ia & $12 / 12$ & & & & \\
\hline $\mathrm{Ib}$ & $28 / 23$ & & & & \\
\hline Ic & $27 / 21$ & & & & \\
\hline Id & $20 / 20$ & & & & \\
\hline II & $29 / 10$ & & & & \\
\hline II & $5 / 5$ & & & & \\
\hline II & $\mathrm{P} / 5$ & & & & \\
\hline III & $26 / 26$ & & & & \\
\hline IV & $3 / 3$ & & & & \\
\hline & \multicolumn{5}{|c|}{ - close antigenic relationship } \\
\hline & \multicolumn{5}{|c|}{ - distant antigenic relationship } \\
\hline & \multicolumn{5}{|c|}{ - lack of antigenic relationship } \\
\hline
\end{tabular}

In serological type II, we included three bacteriophages: 29/10, 5/5, P/5. Bacteriophages of this type were inactivated by all three tested sera, but the sera obtained for bacteriophages $29 / 10$ and $\mathrm{P} / 5$ did not inactivate bacteriophages classified as serological type I.

Bacteriophage $26 / 26$, which was completely inactivated by serum to bacteriophage $29 / 10$ and partially by serum to bacteriophage $\mathrm{P} / 5$, was classified as serological type III.

Finally, bacteriophage $3 / 3$ was assigned to serotype IV, which was not completely inactivated by any of the tested sera, it was partially inactivated only by serum to bacteriophage $29 / 10$ (by $34.85 \%$ ).

As indicated above, we used the serum obtained for the bacteriophage $\mathrm{C}_{14}$ active against bacteria of the genus Enterobacter. As can be seen from the data obtained (Table 2), bacteriophages of serrations were not inactivated by this serum, this suggests that bacteriophages of serrations and bacteriophages of Enterobacter do not have common antigens.

\section{References}

1. I. M. Gabrilovich, Basics of bacteriophagy (1973)

2. I. M. Gabrilovich, A practical guide to bacteriophagy (1968)

3. I. M. Gabrilovich, Characteristics of phages active against bacteria of the genus Serratia, 72 (1990)

4. I. M. Gabrilovich, Zh. Microbiology, Epidemiology and Microbiology, 2, 10 (1992)

5. R. Kh. Gairabekov, Abstracts of the report. United scientific conf. of young sc., spec. and students of "Med. science - to practical health care". Makhachkala, 378 (1990)

6. R. Kh. Gairabekov, All-Union Conference. Microbiological and biotechnological foundations for the identification of crop and forage production. Alma-Ata, 15 (1990) 
7. R. Kh. Gairabekov, Natural and technical sciences, 4, 163 (2011)

8. R. Kh. Gairabekov, Topical issues of studying intestinal infections, Nalchik, 46 (1988)

9. R. Kh. Gairabekov, Natural and technical sciences, 4(54), 163 (2011)

10. M. Adams, Bacteriophages (1961)

11. D. E. Bradley, J. Roy. Microscop. Soc., 84, 257 (1965)

12. I. M. Gabrilovich, 2-nd International Meeting on Bacterial Epidemiological Markers, 268 (1990)

13. A. Gallegos, WHO Declares Public Health Emergency for Novel Coronavirus. Medscape Medical News (2020) https://www.medscape.com

14. CDC. 2019 Novel Coronavirus, Wuhan, China. Centers for Disease Control and Prevention. //www.cdc.gov/coronavirus

15. W. B. Harden, Arthritis and Reum, 23, 946 (1980)

16. H. W. Horwits, J. Clin. Microbial, 25, 1562 (1987)

17. M. Matthews, Proc. 3rd European red. conf. on electron microscopy, 2, 543 (1969)

18. J. L. Pecarrere, Arch. Inst. Pasteur Madagascar, 48, 37 (1979)

19. T. L. Pitt, I. J. Erdman, C. Bucher, J.Hyg., 84, 269 (1980)

20. A. Ramzy, D. G. McNeil, W.H.O. Declares Global Emergency as Wuhan Coronavirus Spreads. The New York Times. https://nyti.ms

21. N. Seifert-Gertchman,Z. aalg. Microbiol., 1, 87 (1960)

22. E. Serruses-Schontens, Eur. J. Clin. Microbial, 3, 316 (1984)

23. The New York Times. Coronavirus Live Updates: W.H.O. Declares Pandemic as Number of Infected Countries Grows. The New York Times. https://www.nytimes.com

24. R. Verral, Infect. Contr., 4, 469 (1983)

25. R. Zbinden, J. Clin. Microbial, 25, 1409 (1938) 